\title{
Gender and Sexuality in Islamic Teachings vs. Human Rights 2017: A Literature Review
}

\author{
Fatma Khattab* \\ * University of South Wales, MBA, United States of America; f.e.eldesouky@sce.aucegypt.edu
}

\begin{abstract}
Resumo
Com as atuais mudanças na liderança política das sociedades muçulmanas, é difícil acompanhar quem lida com as questões das mulheres. Muito menos, como as questões das mulheres são uma grande parte de cada um dos discursos políticos do Liberal ao mais conservador. Enquanto isso, quando se trata de leis e regulamentos sobre questões femininas, não se faz muito para capacitar mulheres ou permitir que estas decidam o que é melhor para elas. É apenas um assunto interessante de discutir mais ou menos, dependendo da necessidade política, enquanto os relatórios mencionam a capital Cairo como uma das cidades menos seguras para as mulheres. Além disso, na sequência da Primavera Árabe, que levou muitos a reconsiderar a luta pela democracia e pelos direitos humanos, desde então as condições socioeconómicas em curso agravam-se para os homens e muito mais para as mulheres. Acharemos difícil acompanhar as melhorias feitas nos direitos das mulheres, enquanto o mesmo antigo discurso religioso pede que as mulheres mantenham sua fé e paciência pelo amor de Deus e por um futuro melhor para a dignidade de seus corpos, mentes e almas. Este artigo discute a situação atual dos direitos das mulheres e como o processo político continua a justificar-se através de razões religiosas, com base na situação atual para manter as mulheres muçulmanas a sofrer.
\end{abstract}

Palavras-chave: direitos humanos; empowerment; fé; género; sexualidade; Ummah; Wahabi

\begin{abstract}
Given recent changes in the political leadership of Muslim societies, it can be difficult to follow who got which hand on women's issues, let alone just how women's issues figure in political speeches from the Liberal to the most conservative. Meanwhile, when it comes to the laws and regulations on women's issues, not much has been done to empower women to decide what is best for them. It's only an appealing matter to discuss more or less, depending on the political need, while recent reports describe the city of Cairo as one of the least safe cities for women. Following the Arab Spring, which pushed many to reconsider the fight for democracy and human rights, socio-economic conditions have been worsening for both men and women, with those in the latter category suffering the most. We may find it challenging to track improvements in the area of women's rights as long as the same old-new religious speech calls on women to keep their faith and patience for God's sake, for a better future for their body, and for the dignity of their mind and soul. This paper discusses the current status of women's rights in Muslim societies and how policy processes are informed by religious justification.

Keywords: empowerment; faith; gender; human rights; sexuality; Ummah; Wahabi
\end{abstract}




\section{Introduction}

It has been a struggle to fully understand the context where I belong, and I have been doing research here and there looking for answers. However, the misleading reality and the interrelated or the overlapping personal interests have covered up for many people, who present themselves as leaders of the developing Muslim Arab World. I did contact many religious preachers, political or social science professors to figure out the main hidden agenda of men in my society but I failed to understand it fully and clearly. This would come to a realization that we as women are living in a Muslim community and we are attached to the mere fact, that this is a male dominated society, and by going further little bit, we'll figure out that all the prophecies came by the hands and voices of men not women. This may be for some reason that women do suffer a monthly menstruation, as well, religion is manly or it looks in its core like Islam is a religion made for men. If we do a quick investigation in any Muslim society, we will get to understand how women have been degraded to a second level or even less from being humans, and some men don't even believe women are humans.

As it seems through my previous research that many aroused, or self-motivated Muslim philosophers, thinkers or religious leaders are always going too far in their self-encouraged image for a more opened understanding of Women's role in Islam and throughout the religious history of the nations. However, this widely positive image is not clear or terribly disturbed by the harsh socio-economic conditions of the Muslim societies in our modern world, as well as, the more these conditions become harsh on men, the worst they become on women as a secondly graded human. Furthermore, in so many trophies nowadays; the Muslims societies are recognized as the most under-developed, under-nourished intellectually, humanely, economically and politically, and this means that no evidence can prove that the mere few idealistic verses of the Qura'n that speak up of women's legacies throughout the human's history are of such impact on the nowadays human life of women, no matter the motivation is to make them look empowered under Islam. Moreover, the harsh conditions in the developing world especially in the Muslim-Arab one can't be isolated from the fact that any empowering policies for women in the educational, health care, judicial or the political field can't stand alone in the face of the evolution or the fast pace changes within these societies.

In this study I will discuss from a feminist, philosophical, religious, psycho-social, economic and political perspective the Gender and its related sexuality in the Islamic teachings vs. human rights literature.

- My main hypothesis then is Most of the Islamic teachings serve as a religion for men compared to human rights conventions.

- Sub-hypothesis:

1. Islamic Teachings in its core assigns men to lead or to dominate women as a second graded human.

2. Islamic Teachings in its core assigns men for full sexual pleasure and not any for women. 
3. Islamic Teachings in its wider sociological image creates a society of homosexuals.

4. Disempowering Muslim women through Islamic Teachings is a long term intended process to provide space for some interests to unleash.

This study reviews some of the previous literature that paid attention to the same aspect of my study, like:

1. Gender Equality according to Islam and Feminism (Bahrami \& Raftari, 2011): this study reflects on how legal discrimination against women creates the social discrimination represented in violence against women. As well, it reflects on how Feminism and Islam defended women's rights.

2. Gender Equity in Islam (A. Badawi, WAMY): this study discusses the different understanding of Islam from a fundamentalist and a legal perspective, and its impact on the Gender equity in the Muslim society but it doesn't discuss any of the related sexual or marriage matters, or reflects on the historical perspective of the Muslim society evolution.

3. Women, Family and Gender in Islamic Law (Tucker, 2008): this study is a good base to build on, however, it is published date is old and it doesn't discuss any of the newly released laws on Gender's equality in any Muslim society or any advances made in the human rights field or any accomplishments done by strong women in the society. As well, it goes further to discuss sexuality of the Muslim women under the Muslim marriage with no referral to the humane, mental and psychological side of it.

4. Gender and Sexuality: Islamic Perspective (Abdelsalam, 2006): this study discusses the Gender and sexuality from an Islamic perspective through the Moderate Islamic trend in the Muslim world. However, it doesn't reflect on any societal or psycho-social side of the study.

\section{Gender and Sexuality from a feminist perspective}

Feminism is the advocacy for women's rights on the grounds of equality of both sexes, and it is important to refer to the massive number of the human rights activists, political scientists, sociologists in a Muslim society like Egypt or many others in the Arab-Muslim World, who come out in public to defend human rights from an Islamic perspective. In other words, it is really crucial to say that there are many actors who are exerting much effort to explain how Islam respects human rights, and how women's dignity is well preserved under Islam. In the actual fact, many women based on my work experience in the human rights, political or developmental field are being oppressed physically, mentally, psychologically, sexually and mostly used for making money. For example, I've met some women who have got to live their lives for example as prostitutes or belly dancers in one of the most conservative Arab 
Gulf countries like Bahrain or Kuwait, where they have to offer sex to make a living. Furthermore, the National Center for Social \& Criminological Research stated that $40 \%$ of the imprisoned prostitutes were forced to prostitution under life threats. Egypt as another example is considered one of the highly favored destination for women and girls to be trafficked. (Egyptian Center for Women's Rights [ECWR], 2012 , p. 20) Furthermore, we can't just pass by the marriage concept in Islam without paying attention to how this simple societal family structure turned in the last centuries to degrade women into another level of humiliation, as we can find in any Muslim society a Muslim man is obliged to pay for the wife's family some money, so as to, marry her or to have kids with her as an obliged condition for the marriage to be complete. In most of the cases, young Muslim women are obliged to accept this fact as a reasonable choice of the nowadays Muslim societies, besides, bringing her full capacity and full acceptance while acting like a pleasing sexual machine to her Muslim man under a Muslim vow. Not to forget, Muslim women are obliged to have kids once they've had sex with their husband from the first time ever, no matter the consequences on her emotionally or psychologically.

\subsection{Feminism in the Society}

It is important also to mention that the struggle is not against what most are thinking of as a religion, it would be fair to say that it is not about the religion itself, as far as it is about its believers, this means that religion in itself is not yet to be harmed. It is not event accepted in any poor Muslim small community to discuss such philosophical matter, and it is pretty obvious what Karl Marx once said "Religion is the opium of the people". This means that for example if were to free and empower the feminine body, this is not to come to ever find a relief, and it's worth mentioning the amount of oppression that's always excused by any religious-extreme leader in any Muslim country like Egypt, to God's hands and will. When the Muslim Brotherhood reached authority in Egypt, the Salafists, and the Wahabis became the political mainstream in this country and they even tried to transform the status quo; especially and maybe mainly how women should look like from the outside in the Muslim society. The years are to pass then and women are yet to reach a fair level of the physical and mental acknowledgments of their rights, and to figure out when it all started or from where it originates, or who got the upper hand in freeing and empowering the women in any Muslim community, this is a dilemma that seems to take longer than it's thought to take. Who can take then the lead and call for a feminine social movement to mobilize the society against the obsolete values, especially with the degrading economic conditions in the country or the entire Arab region, or who can take the blame then. It has come to my understanding that the upper hand in that might be affected by those in authority like the Muslim Brothers in Egypt; who went out to call for women wearing the Hijab "head scarf" for all of them, in other words, they supported the public mainstream for turning the Muslim women in the country into covering theirs heads as soon as possible to survive with the new reality in the country. It is also believed that the Wahabi religious wave coming from Saudi Arabia has affected how women in the Arab region dress up, or how they look 
like, or how most of the Muslim practices are done nowadays. Mostly some would refer to the whole covered up women dresses from head to toes as retreated to the Iranian or the Iraqi women dressing style, and this means in other words an identity crisis that's affecting how the Muslims in the Arab world perceive their religion or its practices. Once the Iraqis arrived in Egypt in 2003, many Egyptians started getting more extremely religious in their daily life matters, not to blame the Iraqi culture or their life style, but to investigate more on what exactly accompanied the Iraqi refugee wave that hit the country Egypt since then. At the end, we can also see the differences in the types of Mosques in the country that started to show up as a Country -led ${ }^{[1]}$, Salafist, or Muslim Brother types of mosques, with each of its own understanding of Islam as a religion and as a political philosophy, but not to say that was even clear, till after the revolution in 2011 in Egypt that brought the Muslim Brothers to authority with their Societal views and we saw how they collapsed internally later on.

\subsection{Feminism in the Qura'n}

If we were to look more on how women are recognized in the Muslims' holy book the Qura'n, we'd find only that Mary the virgin is the only woman mentioned by her name, while all other kind of prominently recognized women as recorded by 24 times in the religion's recorded history of prophecies, are whether referred to as the prophet Imran's wife, the prophet Mosas' mother or sister... etc. (Stowasser, 1994, p. 14). This comes also with the fact that many other prophets are mentioned directly by their names or their missions on Earth, not to forget, that their impacts over the human's history of faith and religion is so prominent to our days. There's a fact that the Qura'n is a religion that used a very obsolete communication language method that paid mostly attention to the societies of that time in the Arabian Peninsula, and this Qura'nic language showed respect only to the society's structure and the hierarchy that were present 14 centuries ago, and this is a matter of challenge that needs to be reversed to be fully understood. Islam in itself then, as a religion speaks only to no societal structure but only to the Arabian Peninsula one, or mostly it has nothing to do with the rest of the world societal needs, except in matters of general ethics or morals or probably rules of nature, if any. Moreover, this means that Islam as a religion cannot address any other society except those societies of the same community structure and hierarchy like those found that day Islam was born. In some collaboration of Islamic studies; they always referred to the fact that Islam came at a time when women were only mentioned by their family references and not their actual names, which means that Islam in its core came with an obsolete message or a communication plan towards women's recognition or achievements in the society.

Accordingly, this has such an impact on women's recognition or empowerment nowadays, as women are mostly observed in our recent lives; they are all only recognized by their dedication to the family, their professional contributions that are only

1. Country-led mosques are managed mainly by the Ministry of National Endowments and directed by Alazhar as the state-led religious institution. 
recognized through their husbands in the field who cover up for them or their family political resources in the parliament. I was told a story one day by one of the female senators in the Upper part of Egypt, that her family is who paid for her successful votes. This means again, Islam as a religion in itself cannot address women's issues like the family struggles, the growing disparities between men and women socially or economically, or even any discrimination or abuse of authority occurring against women's will. Human rights conventions then are not means that are causing any hostility against the available faiths, calling for a revolution, or any other kind of disturbance to the public order. But they are only means for change in the power structure within the society that affects the flow of diversity, creativity and seeking to create a system of checks and balances between both genders.

\subsection{Feminism in the Civil Society}

Going through many of the local NGOs for example in my country Egypt based on my field experience in 2014, and many of the other feminine leaders for human rights, unfortunately we'll find them mostly belonging to the upper-social and the well-educated class. Yet, when it comes to implementing any of the capacity building activities that cover any of the controversial topics, they usually involve women from the lower strata. Moreover, most of the community leaders have got to approach these poor women with a closer look towards their perspective or let's say with a more moderate message rather than a healthy humane one. And to achieve a progress with the combination of these two different levels of the community will take usually a long process of well-done communication and availability of resources, which means that what resonates mostly with these disadvantaged women at the end is probably less than half what's planned to. Female Genital Mutilation (FGM) for example, is prohibited by laws nowadays in Egypt, and when some of the community leaders address the illiterate women in the country, they do that in a way that don't usually send these women a sharp clashing message; like we're totally against FGM. In other words, they agree on such a message like; let's keep these women busy headed like normal with their worries that their daughters may need an FGM surgery like what's happening already in traditions, and we'd achieve then a behavioral change achieved then, when these women refer their daughters to professional surgeons later on to check on them. However, this is not even a guaranteed message especially that many women claimed during one of these sessions that their husbands force them to hold FGM anyway on their daughters regardless of the health-related concerns. Some false conceptions are also available; when some religious leaders are involved in these public awareness sessions, and they make again FGM a mainstream public interest for many mothers, which is not the main aim anyway from such a public session. These community leaders sometimes forget that some of the mothers maybe on the far extreme and they may still believe that any surgical operation held over their daughters' genital part should happen anyway, as a mean of the family control over the feminine body and the feminine mind, although this may be for no health reasons or even traditional one. 


\section{Gender and Sexuality from a religious and Legal perspective}

I've searched through much literature too in my country and the Arab-Muslim region, and as usual I believe that they missed up the conceptions of religion vs. faith. In many of the readings related to spirituality of the religion Islam for example, none of them proved to me that I've got to stick to Islam to find a relief or a good base for human justice or good balanced health and life style. Although Islam assures the freedom of mankind against injustice and against the injustice authority of the Ummah (Muslim Nations) governors, none of the Islamic philosophers' or teachers' efforts exerted in that regard from the Prophet Muhammad Utopian city state to Ibn Tymiya as an example in "The legitimate policy to reform the governor and the governed" (Doredy, 2014, p. 24) managed to achieve that. These teachings never spoke of the much more effective means of fighting against the injustice league of abusive authority, or most probably calling for a revolution against the dictator corrupted authority. Furthermore, they never speak in a way that would cause a social change, so as to, fight against the authoritarian corruption or injustice, although this might be clear in one of the Qur'an verses that say "Allah does not change a people's lot unless they change what is in their hearts" (AlRa'dd, Verse 11). This also has nothing to do with the lack of awareness or enough education available to change the society's obsolete cultural values, but it is again more about the balance of power over the human history between the both sexes. Likewise, we'll find those revolutionary philosophers in their times are whether rejected by their society, their peer thinkers or mostly abandoned by their governors, till it comes a time when all the scholars of these philosophers are ready to speak up for some critical reviews or to bring their teachings back to the light. These scholars' dear interests for some fame or some recognition may be hindering also all of that historical work trying to come to the light finally to bring the Muslim societies to its true faith and integrity to fight against the corrupted authority. This means too that the Islamic teachings have minor impact when it comes to fighting against injustice, abusive authority, and the misconceptions of the Islamic teachings that favor those in authority or looking for some personal advantages.

\subsection{Gender and Sexual violence in Human Rights Conventions}

If we go through some of the human rights conventions, there we'll find much more detailed efforts exerted in favor of women that make us more appreciating these humane efforts than any other Goddess teachings. Yet, if we visit any of the public conferences or discussions for any of the Arab countries, we'll find the regular assurance on how Islam as a religion got the upper hand for the truth and nothing but the truth. However, this truth never spoke most recently of how close we can get to empower women intellectually, economically, socially and politically. On the other hand, we will find these philosophical/legal teachers raise the upper hand of religion above all means, although, no one activist ever tried to contradict Islamic teachings, clash with any Muslim society totally or religion in favor of a certain political or economic class over the other, but mostly these efforts are to support half of the society that 
is women and trying to free their body, minds and soul from any kind of abuse. It is important to mention too, that no one human rights organization claim favoring one case of abused woman over the other, especially that this takes lots of efforts, legal and psychological support, till a woman victim of violence get freed from her trapping abuse.

\subsection{Gender and Sexual violence in Social Movements}

Some social movements and voices started to raise their objections too against the current social status of the many disadvantaged women in the country, also, the era post the 2011 and the 2013 revolutions in Egypt presented in the 2014 constitution adopted; refer to only 1 article no. " 267 " of the penal code for crimes related to "rape, sexual assault and harassment"; as rape considered a crime if it includes a penetration to the vagina, with no referral to other means of sexual rape like oral or anal sex (Euro-Med Rights, 2017, p. 1). This presents a major threat to the feminine safety measures and survival on the Egyptian streets then, if she were to go to school, college, or work to fulfill her personal, mental and family needs.

In the adopted constitution 2014 also article no. 306, stated sexual harassment is considered a crime only if the offenders meant to gain sexual benefits, although some acts might involve the mere physical harassment for cause a feminine discontent by being in a public space no more. This might entail the beginning of further continuous acts of harassment, or any other kinds of threats that disturb the feminine social peace and existence in the public space. Especially, if a woman is at an opposition stands against her other gender, which may lead to regular continuous acts of harassment or any other kind of oppression. Based on my experience; I got exposed mentally and physically to harassment at the place of work, if any of my male co-workers felt superiority or promotion is coming my way. In different words, if I want to feel safe at the place of work, this means I've got to play it safe and act like I'm in agreement with everything happening at the place of work, regardless the fact that some activities ongoing might involve a corruption act by any of the co-workers junior or senior.

\subsection{Gender and Sexual violence in the Egyptian laws}

Article 60 as well, in the constitution allows the offender if acted domestically with violence but for Good reason like wife's punishment to be justified for Good Faith. Also mostly domestically-abused women or daughters find it usually hard to speak of the kind of sexual or physical violence that's happening to them, and how it is affecting their daily life routine in public, mainly for reasons of culture, feeling ashamed for their families, or any other of expected/retroverted acts of the primary offender. Most of the feminine cases of sexual or domestic violence suffer in silence, and it takes a very long time from the victim to come out and prove that any act of violence harmed her body's dignity, mental or social status (Euro-Med Rights, ibid, p. 1). On the other hand, Al-Azhar as the state-led religious institution is yet to release any acts in favor of fighting violence against women (ElBehary, 2017) and this means that regardless 
of the few efforts exerted in favor of the women's body dignity or human rights, this never been a priority for Al-azhar leaders till 2017. No such law enforcement is even supported regardless of the Egyptian ratification on the Convention of Elimination of all forms of Discrimination against Women (CEDAW) in September 1981 until 2015; when the National Council of Women drafted its national strategy to combat forms of discrimination against women in coordination with the Ministry of Interior. Due to the reality checks that would support a more eager governmental instrument with a ready quick response for reported cases of violence against women, which would cost the society's structure, the government's police apparatus and the cultural well-rooted obsolete values big shock (Euro-Med Rights, ibid, p. 2).

With referral to the Egyptian government reservations against the CEDAW; Article 9 the Egyptian authorities found; it is more suitable for the newly born children to acquire their father's nationality to avoid any duality of the child's nationality Article 16 refers to divorce, which is according the Sharia Law; the Muslim husband has to pay for his wife and kids' expenses after the marriage dissolved by divorce, and this requires a judge intervention to make it legitimate. However, the divorcing act is happening here with no referral to the equal distribution of marriage properties after the marriage dissolution according to the article mentioned earlier, and on which Egypt showed its reservations (UN Women, 1981). On the other side the Khul' Law No.1 in 2000 declared that the wife has the full right to divorce her husband on any grounds; under the condition of abandoning all of her financial rights that resulted from marriage, which has its own impact too on the longer term on divorced women and that may hinder many women and hold them back from seeking Khul' (Sonneveld, 2000, p. 1). Referring also to the social outcome of such a legal action; Khul' is not always in favor of women who went through, as well as, the society is not making it any easy for women to feel like socially accepted after all. This is also evidenced in (Survey Panel for Young People in Egypt [SYPE], 2009-14, p. xvi) a survey; that a group of young Egyptians aged (15-29) believe that the society don't show respect to divorced women by any mean by $63.7 \%$ of the surveyed group.

\subsection{Egypt's policy progress on women empowerment}

This means on the other side, that any of the reservations on the articles of the CEDAW (UN Women, 1979) that obliged the committed states to work on or prepare for measures of elimination of all forms of discrimination against women, never entailed any social hostility in themselves, moreover, no public debates disagreed with the convention, or most probably, there were no enough efforts exerted to make it a public debate to bring about a more positive intervention for all forms of discrimination against women. Furthermore, a concluding report issued by the Committee for Elimination of all forms of Discrimination against women; claiming the rise of forms of violence against women, besides that all the social facilities established to help victims of violence put conditions that only favor the elderly women as an example, and they pay attention only to the women aged not less than 50 and that's for any victim to be considered eligible for a protecting shelter (Committee of Elimination of all Forms of Discrimination against Women [CEDAW], 2010, p. 5). 
The clear fact then that any of the efforts established to empower women or to eliminate any forms of discrimination against them were just shelved logically for many years counted. There's no clear indication about when exactly this could happen, especially if we check the Egypt national strategy towards the Sustainable Development Goals 2030, we will find that many of the previously planned sustainable development goals have not been achieved; like women quota of seats per the two chambers of the Egyptian parliament, the number of the working women per paid job away from the agricultural sector (Almogharbel, 2017, p. 6). Whether the current presidency will commit itself to bring about any further or actual space for empowering women or integrating them in the public space personally or professionally, this remain to be a matter of the future to determine. Although the newly elected president Abdelfatah Alsisi announced that 2017 is the year of the Egyptian woman, female representation in Alsisi Cabinet of Ministers does not exceed 6\% of the total presidential appointments (Egypt Cabinet, 2017).

\section{Gender and Sexuality from a psycho-social and economic perspective}

Many of the social restrictions against women do not act in their favor on the intellectual or the professional level; however, it brings more back clashes on the longer term. Many forms of violence against women were justified for arguing with husbands by $40 \%, 35 \%$ for refusing to have sex with husbands (Swiss Development Cooperation [SDC], 2013, p. 6). While other means of psychological violence were confirmed (United States Agency for International Development [USAID], 2009, p. 5) like belittling, acting indifferently towards the woman, sending her direct or indirect threats of harm, insults, a tendency of a controlling behavior against the female victim like isolation or controlling her contact with the surrounding environment.

\subsection{The Sociological and psychological aspects of Gender and sexual violence}

Forms of domestic violence can take place on the female kids or adults, its impact on the female's physical and mental health; ranges from low self-esteem, phases of Post-traumatic Stress Disorder, depression, suicidal attempt, which lead at the end of the day to a full imbalance of the female social, psychological and mental life (Kumar, 2012, p. 274). On the longer term, it leads also to a loss of concentration with a sense of dissociation. The impacts of these psychological acts against women lead to failure in the personal, social and professional life. In other words, if we were to say that women empowerment has taken a rising shot in the last few years, and women are nowadays more enrolled in higher education, employment fairs and human development planning centers (Almogharbel, ibid, p. 6). Most of those women graduated from primary of higher education institutions are under the trauma of domestic violence, young females also might have been subjected to FGM which affect their future sexual lives, or women who are subjected to harassment, bullying (Kumar, ibid, p. 274) on a regular basis for their not so good body or facial shape according to their male peers or employers, and any other forms of violence at the workplace, the educational platform or even the personal life space, all hinder the efforts exerted to 
advance the women's status in most of the developing countries like Egypt. Therefore, we cannot measure the success of a woman's capacity within the current educational or professional spheres without retreating all the educational, financial, social and cultural conditions that have surrounded her life journey in order to judge. Most probably, as this may bring us back to the prominent Islamic teaching or quote of the prophet Muhammad "women are deficient in intelligence" (Bint Younis, 2016). Although this quote is thought not to be accredited by most of the Islamic preachers and teachers, it only refers us to the intended process of degrading the women's physical and mental abilities. Although, women have proved their abilities around the world in building societies, being the main breadwinner for their families, or even reaching the highest level of the decision making process as seen in most of the developed countries. A degrading process that is inherited by generations of men in any developing country and justified by traditions like honor crimes, or justified by the leading/dominating status of men in any poor society, are all measures that impact most of the efforts done towards empowering women.

Meanwhile, most of the modern Islamic preachers started to have their own TV shows probably starting early 2000s, due to the rise of the modern technology and social media platforms. Most of their efforts presented are a recall for reconsidering our understanding of Islam, the connections between the female and the male bodies in the Muslim society and how with better education the Muslim society would advance in a more comprehensive inclusive approach. Unfortunately, they neglected the fact that with a fair share of mutual understanding between science and religion, or between the developed and the under-developed worlds, this would bring us to so many facts ignored and left behind like the mere basic human rights for women; like the right to lead a Muslim country, the right to be a part of the national army, or the right to speak up for herself and her dear personal needs, even if they are merely sexual, and at last, it is important to mention that the emotional life of most women is totally believed to be of a secondary essence to the women's health and life in most of the Muslim developing countries like Egypt. It is hard to tell then, that a big advancement in approaching a more inclusive fair and sustainable share of the human entitlements in a Muslim society that would advance as a result of the new phase of the modernized Islamic guidance or preachers, unless they are attached to a more publicly approved legitimate law of punishment and means of preserving human rights.

\subsection{The economic aspect of Gender and Sexual Violence}

Women's rights have not yet been considered a mainstream, till we started to see the major decline in the economic conditions of the country and that showed a great turn down towards a dangerous level of prevailed poverty, which also reflects upon the vulnerability of the many women and female kids, that are for e.g.: in an interview with 200 female streets kids, showed that $50 \%$ of them proved to offer sex for money, while $30 \%$ of the same group are forced to sex (UNAIDS, 2014, p. 398), and although Al-azhar has managed overtime to bring its in-kind contributions to the disadvantaged women like the widows or the divorced women and mainly the street 
kids under the Law No. 30/1977; in which "orphans are entitled to apply for financial support", the lack of the financial resources, monitoring and supervision of such charities, the sustainability measures for outreach or building the community skills; all resulted in the gap between the needs and the available resources (Arab Urban Development Institute [AUDI], 2004-17, pp. 34-5).

The inclusion of young females also in primary education showed only $43.9 \%$ of the Egyptian women who received a secondary education, while only $23.7 \%$ of the female population recorded by the work force, according to (United Nations Development Program [UNDP], 2015, p. 62) the Human Development Report in 2015, other women recorded as they get paid less 34\% than their male coworkers and other working women find annoyance from their male coworkers (ENID, ibid, pp. 5-6). We can say that although most of the efforts offered are with positive records mentioned under many developmental projects for national and international actors in the field, they do favor only those who reach out for financing as an example; in the field of micro or small projects. As mentioned at the Social Fund for Development website; the main national micro, small and medium sized enterprises (MSMEs) lender; around $1,173,088$ women were covered from 1992 to 2016 by their financing projects (Social Fund for Development [SFD], 2016), although the percentage of female breadwinners under poverty line is $26.3 \%$ (Almogharbel, ibid, p. 11). Even working women have been used most recently in our days as means of economic support to their families, and the most favored ones for the slacking kind of husbands, who like to depend more on somehow educated and working women to push for a more economically stable family structure. This comes with no guarantee for the married woman; if she were to get divorced later, that any of her economic rights are preserved.

In other examples; a survey met with 7 out of 10 parents still plan to FGM their daughters (SYPE, ibid, p: xiii), HIVs/AIDs infections impact married women's health due to their sexually active husbands outside the legitimate Muslim marriage practices (Oraby \& Abdel-tawab, 2016, p. ix). Many women discovered got HIVs infection through heterosexual contact with their already known HIV positive husbands, who they had to accept their illnesses for economic or social reasons, and this is also what I found from my involvement with UNFPA records and their ongoing project activities that try to cover women victims of HIVs infections caused by a spouse in the upper part of Egypt.

Islam then as a religion for the society not the individual believes in the societal core presented in the family structure, and most of the Islamic teachings have not covered the regulations of morals or laws enforcement.However, they are only talking about inheritance or divorcing measures as discussed earlier, these definite Islamic laws regulating marriage against divorce, women against men in inheriting their families' fortunes, have ignored the reality of a very limited education level, and a restricted legal options, that would hold back most of the women from enjoying their mere economic rights. At the end, this leads us to the conclusion that most of the efforts offered in understanding Islam as a religion, or the Qur'an as the holy book or the Prophet's teachings as the main Muslim guidance book are neglected by the societal, the humane and the materialistic conditions surrounding the Muslim 
community overtime and through the different places and crises. As well as, presenting Islam as a mere call for peace and justice without any effective measure to preserve law and order. While it good to mention how many of the post-Arab spring presidents have called and mobilized the impoverished communities in the poor Arab countries to believe that with the Islamic teachings; justice and fairness would prevail. This has come to an end with the collapse of the most religious presidents in the Arab world after the revolution like Egypt and Tunisia and with them collapsed all the hopes of a new dawn of justice.

This raises so many questions about most of the national and international organizations working on human rights that can observe the current status of progress for many developing countries like Egypt towards a new phase of acknowledging women's rights. Also, the current Sustainable Development plans for a more comprehensive inclusive phase of development, which will take another fair period of planning and seeking best results-achieved management for these plans, will require all the stakeholders and actors involved to reconsider their human rights and development plans. To bring about a more cultural and also economic progress in the lives of so many women the Muslim-Arab world, if we were to leave it to religion or the preachers' efforts towards women's empowerment; we've seen how it comes and goes under men's umbrella. Women have no choice or a decision to make, they always follow a plan that they never discussed, an action that they never reached out for, or a result that they never expect to be positively going with their side. That's why it requires a regular cultural and conceptual revision of the ongoing projects' goals, plans and achieved results, besides, by time as we go any further to advance the women's status in any developing country, we see mostly men coming to take over all of the fruitful outcomes. We never saw many advances at once for women's sake, their own preferences or their actual needs, which definitely, brings us to the realization that many of the efforts done were planned and implemented by men, or mostly women who are guided and probably used by men, and let's not ignore the fact that many working human rights or developmental organizations in Egypt fear the outspoken talk of women's rights in public, or they usually try to go with the wind. Women's empowerment then towards their full recognition of rights can never come in full, if men are involved and this will also take a lot of work from the women's side. At last, better not to advance at all than making a progress for women's sake that will be melt within men's basic needs and requirements.

\section{References}

Abdelsalam, A. A. (2006). Gender \& Sexuality: islamic perspective. SARI, 24(2), 35-48. Retrieved from <http://journalarticle.ukm.my/1075/1/Gender_and_Sexuality_-_An_ Islamic_Perspective.pdf (accessed 16 ${ }^{\text {th }}$ of June, 2017) $>$.

Almogharbel, N. (2016). Women in the sustainable development strategy Egypt vision: 2030. Egypt Network for Integrated Development (ENID). Retrieved from < file://C:/Users/ fatma/Downloads/egypt2030.pdf> (accessed 21 $1^{\text {st }}$ of July, 2017). 
Arab Urban Development Institute (AUDI). (2004). Vulnerable children in Egypt: Status, problems, needs \& services offered (Final Report). Arab Urban Development Institute (AUDI). Retrieved from <http://www.araburban.com/files/file/DataBase/CYP/13/ Alexandria.pdf $>$ (accessed 17th of June, 2017).

Badawi, A. J. (1995). Gender equity in Islam. World Assembly of Muslim Youth. Retrieved from <http://www.jannah.org/sisters/genderequity.pdf $>$ (accessed 16 ${ }^{\text {th }}$ of June, 2017).

Bahrami., Z. \& Raftari, H. (2011). Gender equality according to Islam \& Feminism. International Proceedings of Economics Development and Research, 5(2), 492-496. Retrieved from <http://www.ipedr.com/vol5/no2/109-H10263.pdf> (accessed $16^{\text {th }}$ of June, 2017).

Bint Younis, Z. (2016). Women, men and intellectual deficiency. Al-Jumah. Retrieved from $<$ http://aljumuah.com/women-men-and-intellectual-deficiency/> (accessed $21^{\text {st }}$ of July, 2017).

Committee of Elimination of all Forms of Discrimination against Women. (2010). Concluding observation of forms of discrimination against women. Forty Fifth sessions. Retrieved from <http://www2.ohchr.org/english/bodies/cedaw/docs/co/CEDAW-C-EGY-CO-7.pdf> (accessed 17th of June, 2017).

Doredy, A. (2014). Summary: Ibn Tymia The legitimate Policy to Reform the Governor \& the Governed. Retrieved from <http://www.feqhup.com/uploads/1395732510181.pdf> (accessed 21 st of July, 2017).

Egyptian Center for Women's Rights (ECWR). (2012). Report on Egyptian women condition in 2012: Women get out to the streets. Egyptian Center for Women's Rights. Retrieved from http://ecwronline.org/?p=1743 (accessed $21^{\text {st }}$ of July, 2017).

ElBehary, H. (2017). Al-Azhar to issue document to stand up for women's rights in Islam. Egypt Independent. Retrieved from http://www.egyptindependent.com/al-azhar-issue-document-stand-women-s-rights-islam/ (accessed 17th of June, 2017).

Egypt Network for Integrated Development. (2015). Women participation in paid Employment is a matter of policy not a mere ideology. USA: University of Minnesota. Retrieved from <http://www.enid.org.eg/uploads/pdf/PB22_women_employment_assaad. pdf $>$ (accessed 17 th of June, 2017).

EuroMedRights. (2017). Egypt: report situation for violence against women. EuroMedRights. Retrieved from <http://www.euromedrights.org/wp-content/uploads/2017/03/Factsheet-2017-VAW-Egypt-EN.pdf> (accessed 17 ${ }^{\text {th }}$ of June, 2017).

Kumar, R. (2012). Domestic violence and mental health. Delhi Psychiatry Journal. 15(2). Retrieved from <http://medind.nic.in/daa/t12/i2/daat12i2p274.pdf $>$ (accessed $5^{\text {th }}$ July, 2017).

Oraby, D., \& Abdeltawab, N. (2016). Understanding married women's vulnerability to HIV infection in Egypt: An exploratory study. Population Council. Retrieved from $<$ https://www.popcouncil.org/uploads/pdfs/2016RH_WomensVulnerabilityHIV-Egypt. pdf $>$ (accessed 15 th July, 2017).

Roushdy, R., \& Sieverding, M. (2015). Panel survey of young people in Egypt 2014: Generating evidence for policy, programs, and research. Cairo: Population Council. Retrie- 
ved from <https://www.popcouncil.org/uploads/pdfs/2015PGY_SYPE-PanelSurvey. pdf $>$ (accessed $17^{\text {th }}$ of June, 2017).

Sadek, G. (2016). Egypt: sexual violence against women. Global Law Research Center. Retrieved from <https://www.loc.gov/law/help/sexual-violence-against-women/sexual-violence-against-women-egypt.pdf $>$ (accessed 17th of June, 2017).

Social Fund for Development. (2016). Women \& microenterprises. Social Fund for Development. Retrieved from <http://www.sfdegypt.org/web/sfd/women-andmicrofinance-projects;jsessionid=7CA42C62EB0DFAB41C8C80577A46D897> (accessed $17^{\text {th }}$ of July, 2017).

Somach, S., \& Abouzeid, G. (2009). Egypt violence against women study. United States Agency for International Development. Retrieved from <http://pdf.usaid.gov/pdf_ docs/Pnadq891.pdf> (accessed 16 ${ }^{\text {th }}$ of July, 2017).

Sonneveld, N. (2000). The implementation of the Khul Law in Egypt: some preliminary results. Recht Van de Islam, 21, 21-35. Retrieved from <http://www.verenigingrimo.nl/ wp/wp-content/uploads/recht21_sonneveld.pdf $>$ (accessed 17th of June, 2017).

Stowasser, B. (1994). Women in Qura'n: Traditions \& interpretations. NY: Oxford University Press. Retrieved from <http://www.islamicbulletin.org/free_downloads/women/women_in_the_quran.pdf $>$ (accessed $17^{\text {th }}$ of June, 2017).

Swiss Development Cooperation. (2013). Fact Sheet: violence against women, a missing MDG. Women Living Under Muslim Laws. Retrieved from < http://www.wluml.org/ sites/wluml.org/files/resource_en_225610.pdf> (accessed 17th of June, 2017).

The Arab Republic of Egypt. (2017). The Cabinet line-up. The Cabinet. Retrieved from <http:// www.cabinet.gov.eg/Arabic/Cabinet/TheCabinetLineup/Pages/TheCabinetLineup. aspx $>$ (accessed 21 $1^{\text {st }}$ of July, 2017).

Tucker, J. (2008). Women, family \& gender in Islamic law. Themes in Islamic Law. Cambridge. Retrieved from <http://ebook.umaha.ac.id/E-BOOK\%20OF\%20ISLAM/ ISLAMIC\%20LAW/\%5BJudith_E._Tucker\%5D_Women,_Family,_and_Gender_in_ Is(BookFi.org).pdf $>$ (accessed 16 ${ }^{\text {th }}$ of June, 2017).

Ummah O. Surat Al Ra'dd. Verse 11. Retrieved from <https://www.oneummah.net/quran/ book/13.html> (accessed 16 ${ }^{\text {th }}$ July, 2017).

UNAIDS. (2014). Global AIDs response report. UNAIDS. Retrieved from <http://files. unaids.org/en/media/unaids/contentassets/documents/unaidspublication/2014/ UNAIDS_Gap_report_en.pdf $>$ (accessed 17th of June, 2017).

United Nations Development Program. (2015). Human Development report. United Nations Development Programme-Human Development Reports. Retrieved from <http:// hdr.undp.org/sites/default/files/2015_human_development_report_1.pdf> (accessed $17^{\text {th }}$ of June, 2017).

United Nations for Women. (1979). Text of the Convention. United Nations. Retrieved from $<$ http://www.un.org/womenwatch/daw/cedaw/cedaw.htm> (accessed 17th of June, 2017).

United Nations for Women. (1981). Declarations, reservations and objections to CEDAW. United Nations. Retrieved from <http://www.un.org/womenwatch/daw/cedaw/reservations-country.htm $>$ (accessed $17^{\text {th }}$ of June, 2017). 


\title{
Sobre a autora
}

fatma кнаттав é formada em Ciências Políticas na Universidade do Cairo, durante a formação conseguiu, nos últimos anos, pesquisar diferentes tópicos políticos, socioeconómicos e humanitários com foco em projetos educacionais, industriais, ambientais e de saúde. Está atualmente matriculada num estudo de MBA com South Wales University no Reino Unido. Trabalha com grupos de oposição política e de direitos humanos com organizações internacionais de desenvolvimento, ainda que seja difícil comprometer-se com essa vida profissional, devido às condições de trabalho no Egito para as mulheres em geral e para os investigadores políticos mais especificamente. Geriu horas extras para satisfazer o desejo dos diferentes estudos de políticas, estando atualmente envolvida num grupo de investigação para um projeto de angariação de recursos com uma agência de notícias de Porto Rico que representa a liberdade de expressão nos Estados Unidos. Trabalhou também em pesquisa sobre drogas na Índia com o Central Drugs Research Institute. Conseguiu adicionar alguma experiência em empreendedorismo, trabalhando na criação de conteúdo online de startups de tecnologia para o AMD Law Group em Atlanta, GA, e no trabalho de comunicação dos doadores no plano de marketing da organização Seaside Sustainability em Essex, Ma EUA.

\begin{abstract}
About the author
fатма кнаттав is majored in Political Science at Cairo University. As an undergraduate, she managed over the last few years to research different political, socioeconomic and humanitarian topics with a focus on educational, industrial, environmental and health projects. Currently, she is enrolled in an MBA program at South Wales University in the UK. With international development organizations, she has worked in the areas of political opposition and human rights groups, although, due to work conditions in Egypt for women in general and political researchers more specifically, it is difficult to commit to such a career path. She has also studied different aspects of policy research and is currently engaged in a research group for a fundraising project, sponsored by a Puerto Rican news agency, representing the fight for freedom of speech in the USA. She is also working on drugs research in India with the Central Drugs Research Institute. Khattab has also received experience in business management and entrepreneurship through her work on online content creation for tech-startups' for AMD Law Group in Atlanta, GA, USA and donors' communication work while handling the marketing plan for the Seaside Sustainability organization in Essex, MA, USA.
\end{abstract}

